\title{
Resistance to root knot nematode, Meloidogyne naasi (Franklin) transferred from Aegilops variabilis Eig to bread wheat
}

\author{
MQ Yu 1, F Person-Dedryver 2, J Jahier 1 \\ with the technical assistance of D Pannetier 2 , AM Tanguy $1, P$ Abelard 1 \\ 1 INRA, Station d'Amélioration des Plantes; \\ 2 INRA, Laboratoire de Zoologie, BP 29, 35650 Le Rheu, France
}

(Received 30 January 1990; accepted 20 May 1990)

\begin{abstract}
Summary - No genotype of bread wheat has been known to be resistant to cereal root knot nematode Meloidogyne naasi, although wheat relatives including Aegilops variabilis display complete resistance. In the progeny of the cross Triticum aestivum $\mathrm{cv}$ Chinese Spring $\times$ Aegilops variabilis no 1 , lines as completely resistant as the Aegilops parent were selected. A dominant gene is involved in the resistance in this novel material, which did not present gall but sometimes root growth arrest when infested by $M$ naasi. Cytogenetical analysis showed that the length of the alien segment is short or perhaps reduced to the gene itself. Either in the heterozygous state or in the homozygous state, alien information seems to have no negative effect either on the regularity of meiotic behaviour or on chromosomal stability. The value of the introgression into the wheat is discussed.
\end{abstract}

resistance to nematode / Meloidogyne naasi / wheat / Aegilops variabilis / introgression

Résumé - Transfert d'Aegilops variabilis dans le blé tendre, de la résistance au nématode à galle, Meloidogyne naasi (Franklin). Jusqu'à présent, on ne connaissait aucune lignée ou variété de blé tendre résistante à Meloidogyne naasi, nématode à galle des céréales. Par contre, des espèces voisines du blé dont Aegilops variabilis présentent une résistance totale. Dans la descendance en rétrocroisement de l'hybride interspécifique (Triticum aestivum L cv Chinese Spring $\times$ Aegilops variabilis $n^{\circ} 1$ ), des lignées de blé à $2 n=42$ chromosomes possédant une résistance totale comme le parent Aegilops ont été sélectionnées (fig 1). Cette résistance est monogénique dominante (tableau I). Elle se caractérise par l'absence de galle et parfois l'induction d'arrêts de croissance des racines infestées (fig II). L'analyse cytogénétique de l'introgression a montré que la longueur du segment transféré est courte, voire réduite au seul gène de résistance. Que ce soit à l'état homozygote ou à l'état hétérozygote, l'information étrangère introduite ne semble avoir aucun effet négatif ni sur la régularité méiotique ni sur la stabilité chromosomique du matériel (tableau II). L'introgression pourrait être le résultat d'une recombinaison homéologue ou d'une translocation spontanée. L'originalité du matériel produit réside dans le fait qu'ill constitue les seuls blés totalement résistants à $\mathrm{M}$ naasi. La sélection de variétés résistantes est envisageable.

résistance aux nématodes / Meloidogyne naasi / blé / Aegilops variabilis / introgression

\section{INTRODUCTION}

The cereal root knot nematode, Meloidogyne naasi can have a serious effect on the yield of wheat crops (Caubel et al, 1972; Kilpatrick et al, 1976; Gooris and d'Herbe, 1977; PersonDedryver, 1986). No fully effective resistance has been found so far in bread wheat, Triticum aestivum L (Person-Dedryver, 1985). Therefore, improvement of its level of resistance was envisaged through exploitation of interspecific or intergeneric hybrids.
Searches for resistance in wheat relatives belonging to the tribe Hordae were made. In the subtribe Hordeinae, Cook and York (1981) identified resistance to $M$ naasi in Hordeum vulgare $\mathrm{L}, H$ chilense $\mathrm{L}$ and $H$ jubatum $\mathrm{L}$. In the subtribe Triticinae to which wheat belongs, PersonDedryver and Jahier (1985) detected a complete resistance to the nematode in some lines of $A e$ gilops variabilis $(2 n=28$, UUS'Sv) and $A e$ umbellulata $(2 n=14, \mathrm{UU})$ the donor of the $U$ genome of $\mathrm{Ae}$ variabilis. Resistance of these Aegilops species is due to their ability to sup- 
press both the development of the larvae into females and nematode reproduction. In other lines of these Aegilops, the root galls produced in response to invasion indicate susceptibility. Screening for resistant lines has involved selecting lines presenting few or no galls. The line number 1 of $A e$ variabilis belonging to the collection of the INRA Station in Le Rheu was found resistant to both $M$ naasi and Heterodera avenae, the cereal cyst nematode which also has a severe incidence on wheat (Meagher, 1977; Esmenjaud et al, 1987; Rivoal and Sarr, 1987).

The introduction into bread wheat of its genes of resistance to both pests was undertaken. This paper reports on the first lines of wheat resistant to $M$ naasi derived from a cross between this $A e$ gilops and wheat.

\section{MATERIAL AND METHODS}

The wheat line Chinese Spring was crossed as female with $A e$ variabilis no 1 . The $F_{1}$ hybrid was successive- ly backcrossed twice as female to the varieties Rescler and Lutin. Progenies of 1 Back-Cross 2 plant were followed in self pollination as far as the $F_{5}$ generation and backcrossed to Lutin in $F_{3}$ (fig 1 ).

Evolution of the material was cytologically studied. Chromosome counting was carried out using a standard Feulgen technique. For meiotic analysis, anthers at first metaphase of meiosis were fixed in Carnoy's fixative (3:1) then squashed in $1 \%$ acetocarmine.

Seeds were disinfected in $0.2 \% \mathrm{HgCl}_{2}$ in a $95 \%$ alcoholic solution and grown individually on Agar $(20 \mathrm{~g} / \mathrm{l})$ in Petri dishes using the technique described by Person-Dedryver (1984). The first root developed was taken for chromosome counting. The plants were infected with larvae of a $M$ naasi population collected in Le Rheu, when the 3 following roots were between 1.5-3 $\mathrm{cm}$ long. About 70 juveniles were injected on to the agar of each Petri dish with a hypodermic syringe. The Petri dishes were placed in a growth chamber at 20 $21^{\circ} \mathrm{C}$ under a $16 \mathrm{~h}$ photoperiod. The observation of the plants and the counting of the galls developed per plant were carried out from 14-21 d after inoculation of the larvae. The plants found resistant with 0.1 or 2 galls per plant were grown in pots in a greenhouse.

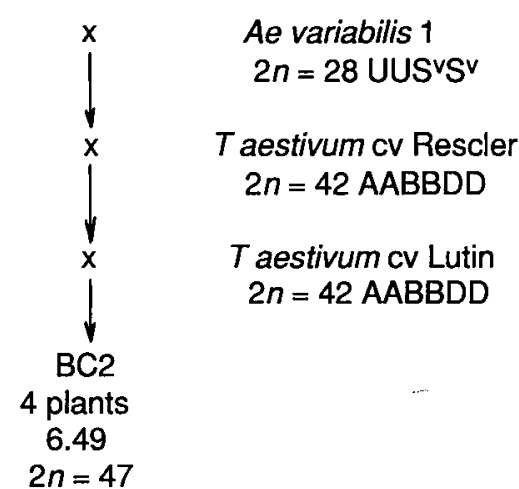

Ae variabilis 1

$$
2 n=42 \text { AABBDD }
$$

F1

$2 n=35$ ABDUSv

$\mathrm{BC} 1$

Plant $62 n=56$

\section{pring}

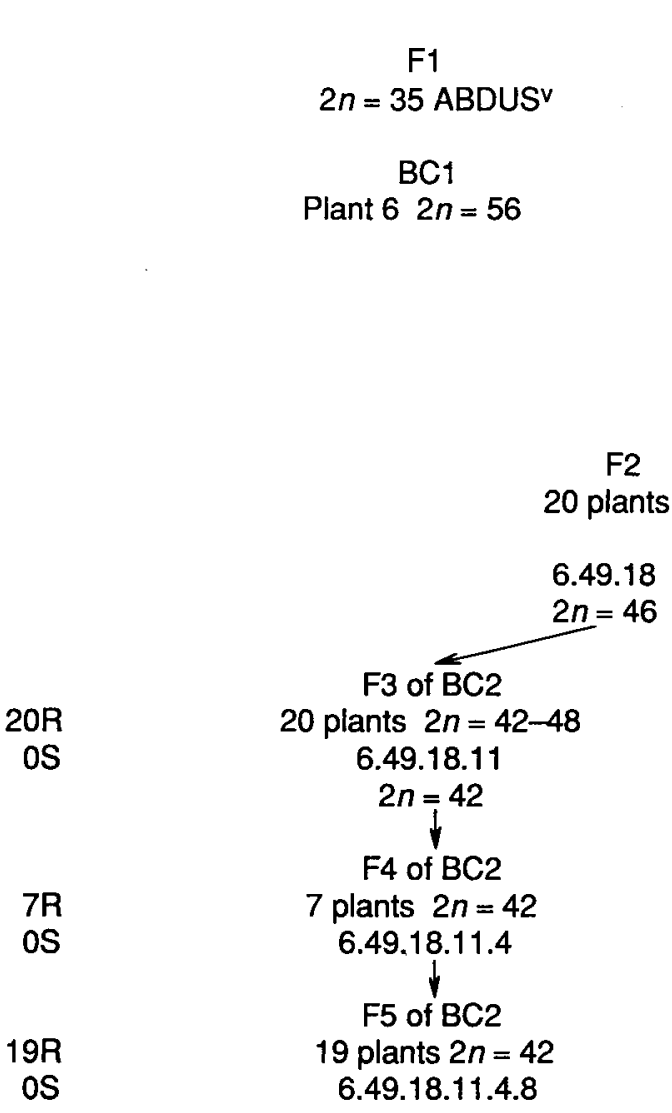

of
1R

3S

$14 R$

$6 S$

6.49 .17

$2 n=46$

20 plants $2 n=42-47 \quad 13 R$

6.49.17.3 x Lutin 7S

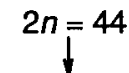

$\mathrm{F} 1$ of $\mathrm{BC} 3$

7 plants $2 n=42 \quad 7 \mathrm{R}$

6.49.17.3.3 OS

F2 of BC3

10 plants $2 n=42$

6.49.17.3.3.9 3S

Fig 1. Steps in producing lines resistant to Meloidogyne naasi. The numbers of resistant (R); and susceptible (S) plants are given. 


\section{RESULTS}

\section{Selection of resistant lines}

In each generation, the wheat lines Chinese Spring, Rescler and Lutin were good hosts for the nematode (fig $2 \mathrm{C}$ ). Only the results concerning Lutin are recorded in table I. Ae variabilis no 1 (fig 2A) rarely formed 1 or 2 galls per plant. Plants selected in the backcross (BC) progenies of the interspecific hybrid were most often without galls or in some cases with 1 gall. In 2 cases plants with 2 galls were retained $\left(F_{2}\right.$ and $F_{5}$ of $\mathrm{BC}_{2}$ ) but their resistance could not be called into question since many more galls developed on the susceptible controls in the 2 corresponding tests and since their progenies were resistant. The genealogy of the material selected at each generation is presented in figure 1 .

$\mathrm{F}_{1}$ hybrid Chinese Spring $\mathrm{x}$ Ae variabilis no 1 displayed the same behaviour to the nematode as the resistant parent. $\mathrm{BC}_{1}$ plant no 6 with 56 chromosomes was backcrossed to Lutin. From the $4 \mathrm{BC}_{2}$ plants obtained, only one (6.49) with 47 chromosomes was gall-free. Twenty plants from the self-pollination of this latter were analysed. A segregation for resistance showed the presence of a dominant gene $\left(\chi^{2}=0.267\right)$ (table I). Among the 14 plants found to be resistant, 6.49.17 and 6.49.18 with 46 chromosomes were selfed.

Progenies of 6.49 .18 were observed in $F_{3}, F_{4}$ and $F_{5}$ of $B C_{2}$. In each generation, all the plants were resistant and had 42 chromosomes.

Twenty plants of the self progeny of 6.49 .17 were tested for resistance. Thirteen of them were resistant including 6.49.17.3 with 44 chromosomes which were crossed with Lutin. The 7 plants in $F_{1}$ of $B C_{3}$ were all found resistant including 6.49.17.3.3 which had 42 chromosomes. The segregation for resistance in the self progeny of this plant was: 7 resistant, 3 susceptible and confirmed that only 1 gene is involved in the resistance.

The resistant material including $A e$ variabilis no 1 displayed 2 types of resistance. In the same line, no gall developed on roots in contact with the parasite and the plant showed: I - a growth stop (fig 2A,B), or II - a growth non altered. Sometimes the 2 resistant types were observed on the roots of the same plant. There was visible reaction of the plant when the growth of roots was stopped, probably if the sites of penetration of many larvae were close to each other. If the 2 types were induced by 2 different quantities of larvae penetrating in the roots of a plant, they probably do not express 2 different genetical determinisms of resistance.

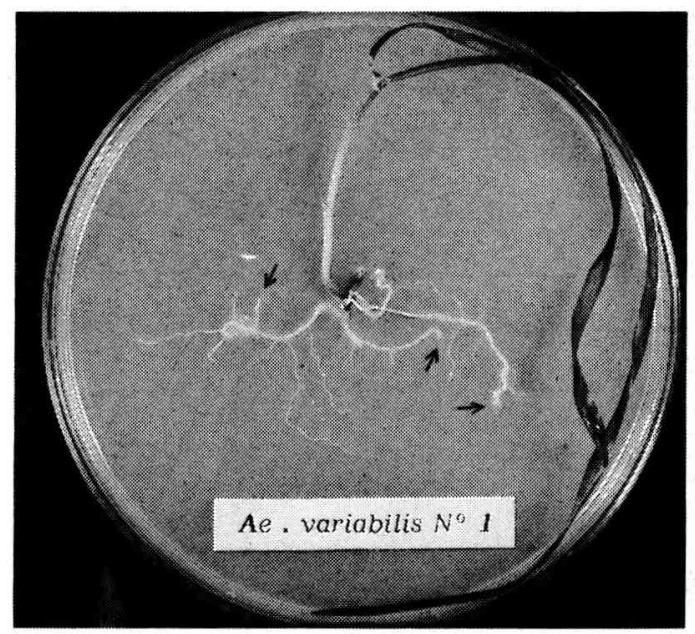

a

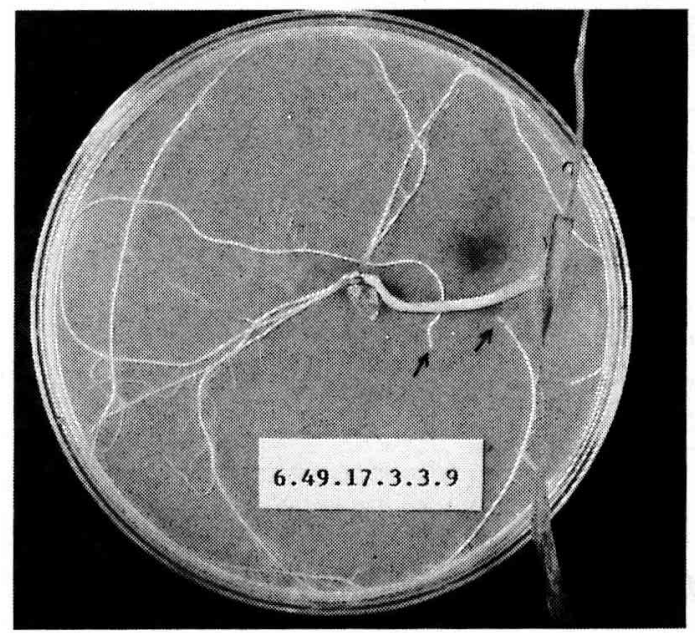

b

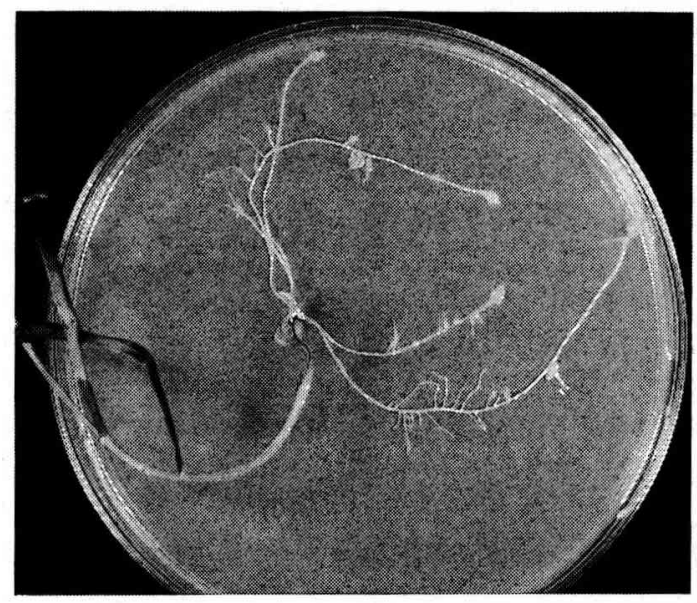

c

Fig 2. Root systems $15 \mathrm{~d}$ after inoculation with $M$ naasi of : A) $\mathrm{Ae}$ variabilis no 1 (without gall); B) a resistant plant derived from the cross $\mathrm{CS} \times A e$ variabilis no 1 (arrows indicate root growth arrests); C) the susceptible wheat Lutin (with galls). 
Table I. Distribution of the plants susceptible or resistant to Meloidogyne naasi in the different generations issued from the cross Chinese Spring $\times$ Ae variabilis no 1 .

Material with the same figure in brackets were tested at the same time with the same susceptible control. CS : Chinese Spring.

\begin{tabular}{|c|c|c|c|c|c|c|c|c|c|c|c|}
\hline \multirow{3}{*}{ Material } & \multirow{3}{*}{$\begin{array}{l}\text { No of } \\
\text { plants }\end{array}$} & \multirow{3}{*}{$\begin{array}{c}\text { No of } \\
\text { chromosomes }\end{array}$} & \multicolumn{3}{|c|}{$\begin{array}{r}\text { Resistant Plants } \\
\text { No of galls }\end{array}$} & \multicolumn{3}{|c|}{$\begin{array}{l}\text { Susceptible plants } \\
\text { No of galls }\end{array}$} & \multirow{3}{*}{ Mode } & \multirow{3}{*}{$\chi^{2}$} & \multirow{3}{*}{$P$} \\
\hline & & & No of & & ant & No of & & lant & & & \\
\hline & & & & $\bar{x}$ & Range & & $\bar{x}$ & Range & & & \\
\hline $\begin{array}{l}\mathrm{F}_{1} \text { C Sx Ae var } 1 \\
\text { Chinese Spring } \\
\text { Ae variabilis } 1\end{array}$ & $\begin{array}{l}20 \\
20 \\
20\end{array}$ & $\begin{array}{l}34-36 \\
42 \\
28\end{array}$ & 20 & $\begin{array}{l}0.1 \\
0.1\end{array}$ & $\begin{array}{l}0-1 \\
0-1\end{array}$ & 20 & 21.6 & $9-45$ & & & \\
\hline $\begin{array}{l}\mathrm{BC}_{2} \\
\text { Lutin }\end{array}$ & $\begin{array}{r}4 \\
11\end{array}$ & $\begin{array}{l}47 \\
42\end{array}$ & 1 & 0 & 0 & $\begin{array}{r}3 \\
11\end{array}$ & $\begin{array}{l}6.3 \\
4.5\end{array}$ & $\begin{array}{l}3-12 \\
1-11\end{array}$ & & & \\
\hline $\begin{array}{l}\mathrm{F}_{2} \text { of } \mathrm{BC}_{2} \\
\text { Lutin }\end{array}$ & $\begin{array}{l}20 \\
13\end{array}$ & $\begin{array}{c}43-50 \\
42\end{array}$ & 14 & 0.4 & $0-2$ & $\begin{array}{r}6 \\
13\end{array}$ & $\begin{array}{r}9.0 \\
12.5\end{array}$ & $\begin{array}{l}7-13 \\
6-26\end{array}$ & 3R:1S & 0.267 & $>0.60$ \\
\hline $\begin{array}{l}\mathrm{F}_{3} \text { of } \mathrm{BC}_{2}(1) \\
(6.49 .18) \\
\text { Lutin }\end{array}$ & $\begin{array}{l}20 \\
19\end{array}$ & $\begin{array}{c}42-48 \\
42\end{array}$ & 20 & 0.1 & $0-1$ & 19 & 7.0 & 3-19 & & & \\
\hline $\begin{array}{l}\mathrm{F}_{4} \text { of } \mathrm{BC}_{2}(2) \\
\text { Lutin }\end{array}$ & $\begin{array}{l}7 \\
7\end{array}$ & $\begin{array}{l}42 \\
42\end{array}$ & 7 & 0 & 0 & 7 & 32.0 & $23-42$ & & & \\
\hline $\begin{array}{l}\mathrm{F}_{5} \text { of } \mathrm{BC}_{2}(3) \\
\text { Lutin }\end{array}$ & $\begin{array}{l}19 \\
20\end{array}$ & $\begin{array}{l}42 \\
42\end{array}$ & 19 & 0.3 & $0-2$ & 20 & 27.9 & $11-41$ & & & \\
\hline $\begin{array}{l}\mathrm{F}_{3} \text { of } \mathrm{BC}_{2}(1) \\
(6.49 .17) \\
\mathrm{F}_{1} \text { of } \mathrm{BC}_{3}(2) \\
\mathrm{F}_{2} \text { of } \mathrm{BC}_{3}(3)\end{array}$ & $\begin{array}{r}20 \\
7 \\
10\end{array}$ & $\begin{array}{c}43-46 \\
41-42 \\
42\end{array}$ & $\begin{array}{r}13 \\
7 \\
7\end{array}$ & $\begin{array}{l}0 \\
0 \\
0.4\end{array}$ & $\begin{array}{l}0 \\
0 \\
0-1\end{array}$ & 7 & 10.6 & $\begin{array}{c}4-17 \\
16-49\end{array}$ & $\begin{array}{l}3 R: 1 S \\
3 R: 1 S\end{array}$ & $\begin{array}{l}1.067 \\
0.133\end{array}$ & $\begin{array}{l}>0.30 \\
>0.70\end{array}$ \\
\hline
\end{tabular}

\section{Meiotic behaviour in the resistant plants}

Chromosome pairing at metaphase I of meiosis was analysed in plants selected at each generation except in $\mathrm{F}_{1}$ and $\mathrm{F}_{2}$ of $\mathrm{BC}_{2}$ (table II).

Most of the 35 chromosomes of the $F_{1}$ hybrid Chinese Spring $x$ Ae variabilis no 1 did not pair $\left(\vec{x}=30.61\right.$ univalents ). Plant $\mathrm{BC}_{1}$ no 6 with 56 chromosomes is characterized by a relatively high level of asynapsis ( $\vec{x}=19.50$ univalents) and by a mean of 2.5 multivalents per cell. In $\mathrm{F}_{3}$ of $\mathrm{BC}_{2}$, plant 6.49.17.3 $(2 n=44) 2$ chromosomes remained systematically unpaired and the plant 6.49.18.11 had a meiosis almost as regular as that of the wheat lines Chinese Spring and Lutin. The chromosome pairing measured by the mean number of paired arms per cell in the plants selected in the next 2 generations was comparable to that of the controls. More particularly, many pollen mother cells (PMC) with 21 ring bivalents were observed in each of the $2 n=$ 42 chromosome selected plants.

\section{DISCUSSION}

The $F_{1}$ hybrid "Chinese Spring $x$ Ae variabilis no 1 " had the expected chromosome number of $2 n=35$ (genomes ABDUSv). The observed meiotic pairing in its PMCs was close to that reported by Driscoll and Quinn (1970). As the amount of pairing was very low and there was no evidence that rare bivalents observed were between chromosomes of wheat and Aegilops it appeared that the probability of recovering a recombination line resistant to the nematode was low and that resistant genotypes that could be selected in the progenies would be addition line(s).

$\ln F_{3}, F_{4}$ and $F_{5}$ of $B C_{2}$ at the origin of the homozygous resistant line $(6.49 .18 .11 .4)$ all the plants were found to be resistant. The plant $F_{2}$ of $\mathrm{BC}_{2}$ 6.49.18 was therefore homozygous for resistance. In $\mathrm{F}_{3}, \mathrm{~F}_{4}$ and $\mathrm{F}_{5}$ meiotic chromosome pairing was analysed in 1 plant. It appears that meiotic regularity was comparable to that of Chinese Spring or Lutin indicating that homozygoty 
Table II. Meiotic chromosome pairing in the parents and in the resistant plants selected in the progenies of the cross Chinese Spring x Ae variabilis. * Mean. ${ }^{* *}$ Range, CS : Chinese Spring.

\begin{tabular}{|c|c|c|c|c|c|c|c|c|c|}
\hline \multirow{3}{*}{ Material } & \multirow{3}{*}{$\begin{array}{l}\text { Chromo- } \\
\text { some, } 2 \mathrm{n}\end{array}$} & \multirow{3}{*}{$\begin{array}{l}\text { No of } \\
\text { Cells }\end{array}$} & \multicolumn{7}{|c|}{ Chromosome association (mean no /cell) } \\
\hline & & & \multirow[t]{2}{*}{1} & \multicolumn{3}{|c|}{ II } & \multirow[t]{2}{*}{ III } & \multirow[t]{2}{*}{ IV } & \multirow{2}{*}{$\begin{array}{l}\text { Paired } \\
\text { arms }\end{array}$} \\
\hline & & & & Total & Rod & Ring & & & \\
\hline $\mathrm{F}_{1} \mathrm{C}$ SxAe varno 1 & 35 & 90 & 30.61 & 2.09 & 2.07 & 0.02 & 0.06 & 0.01 & 2.26 \\
\hline $\mathrm{BC}_{1}(\mathrm{no} 6)$ & 56 & 6 & 19.50 & 14.17 & 7.00 & 7.17 & 1.83 & 0.66 & 27.64 \\
\hline $\begin{array}{l}\mathrm{F}_{2} \text { of } \mathrm{BC}_{2}(6.49 .17 \\
\text { and } 6.49 .18)\end{array}$ & 46 & & & & & & & & \\
\hline $\begin{array}{l}\mathrm{F}_{3} \text { of } \mathrm{BC}_{2} \\
(6.49 .18 .11)\end{array}$ & 42 & 74 & $\begin{array}{l}0.30^{\star} \\
(0-2)^{\star *}\end{array}$ & $\begin{array}{l}20.85 \\
(20-21)\end{array}$ & $\begin{array}{r}2.54 \\
(0-7)\end{array}$ & $\begin{array}{c}18.31 \\
(14-21)\end{array}$ & & & 39.16 \\
\hline $\begin{array}{l}\mathrm{F}_{4} \text { of } \mathrm{BC}_{2} \\
6.49 .18 .11 .4)\end{array}$ & 42 & 54 & $\begin{array}{r}0.07 \\
(0-2)\end{array}$ & $\begin{array}{l}20.96 \\
(20-21)\end{array}$ & $\begin{array}{r}2.31 \\
(0-5)\end{array}$ & $\begin{array}{c}18.65 \\
(16-21)\end{array}$ & & & 39.61 \\
\hline $\begin{array}{l}\mathrm{F}_{5} \text { of } \mathrm{BC}_{2} \\
(6.49 .18 .11 .4 .8)\end{array}$ & 42 & 55 & $\begin{array}{r}0.07 \\
(0-2)\end{array}$ & $\begin{array}{l}20.93 \\
(20-21)\end{array}$ & $\begin{array}{r}1.95 \\
(0-5)\end{array}$ & $\begin{array}{c}18.98 \\
(16-21)\end{array}$ & & & 39.91 \\
\hline $\begin{array}{l}\mathrm{F}_{3} \text { of } \mathrm{BC}_{2} \\
(6.49 .17 .3)\end{array}$ & 44 & 25 & $\begin{array}{r}2.16 \\
(2-4)\end{array}$ & $\begin{array}{c}20.84 \\
(19.21)\end{array}$ & $\begin{array}{c}3.88 \\
(1.8)\end{array}$ & $\begin{array}{c}17.08 \\
(13-20)\end{array}$ & & $\begin{array}{r}0.04 \\
(0-1)\end{array}$ & 38.16 \\
\hline $\begin{array}{l}\mathrm{F}_{1} \text { of } \mathrm{BC}_{3} \\
(6.49 .17 .3 .3)\end{array}$ & 42 & 47 & $\begin{array}{r}0.04 \\
(0-2)\end{array}$ & $\begin{array}{l}20.98 \\
(20-21)\end{array}$ & $\begin{array}{r}2.09 \\
(0-5)\end{array}$ & $\begin{array}{c}18.98 \\
(16-21)\end{array}$ & & & 39.87 \\
\hline $\begin{array}{l}\mathrm{F}_{2} \text { of } \mathrm{BC}_{3} \\
(6.49 .17 .3 .3 .9)\end{array}$ & 42 & 59 & $\begin{array}{r}0.14 \\
(0-2)\end{array}$ & $\begin{array}{l}20.93 \\
(20-21)\end{array}$ & $\begin{array}{r}1.61 \\
(0-7)\end{array}$ & $\begin{array}{c}19.32 \\
(14-21)\end{array}$ & & & 40.25 \\
\hline Ae variabilis no 1 & 28 & 57 & & 14.00 & $\begin{array}{l}1.79 \\
(0-4)\end{array}$ & $\begin{array}{c}12.21 \\
(10-14)\end{array}$ & & & 26.21 \\
\hline CS & 42 & 50 & $\begin{array}{r}0.08 \\
(0-2)\end{array}$ & $\begin{array}{l}20.96 \\
(20-21)\end{array}$ & $\begin{array}{r}1.56 \\
(0-5)\end{array}$ & $\begin{array}{c}19.40 \\
(16-21)\end{array}$ & & & 40.36 \\
\hline Lutin & 42 & 64 & & 21.00 & $\begin{array}{c}0.92 \\
(0-4)\end{array}$ & $\begin{array}{l}20.08 \\
(17-21)\end{array}$ & & & 41.08 \\
\hline
\end{tabular}

for the alien information had no negative effect on pairing. However, this gave no further information on the nature of the alien introduction.

The resistant plants in $\mathrm{F}_{1}$ of $\mathrm{BC}_{3}$ from the cross between 6.49.17.3 $\left(\mathrm{F}_{3}\right.$ of $\left.\mathrm{BC}_{2}\right)$ and Lutin were heterozygous for the gene(s) of resistance which is (are) dominant. The meiotic behaviour observed in the plants with 42 chromosomes including 6.4.17.3.3 was regular. More noticeably the chromosomes of $13 \%$ of the PMCs at metaphase I of meiosis formed 21 ring bivalents. This clearly showed that the transfer did not concern 1 entire chromosome or chromosomal arm of $\mathrm{Ae}$ variabilis no 1 carrying the resistance. A short alien segment was introduced into wheat so that pairing between the chromosome carrying it and its homologue was not disturbed at all. This also resulted in chromosomal stability in the progenies of the resistant plant; indeed all the plants in $F_{4}$ and $F_{5}$ of $B C_{2}$ and in $F_{1}$ and $F_{2}$ of $B C_{3}$ were found to be euploid ( $2 n=42$ chromosomes).

The nature of the alien introduction has not yet been defined. Did it originate spontaneously or through homoeologous recombination? Miller et al (1988) laid emphasis on the relatively high frequency of spontaneous non-Robertsonian translocations between Ae comosa 2M chromosome and its wheat homoeologous. As a low amount of meiotic pairing was found in $F_{1}$ hybrid 
Chinese Spring $\times$ Ae variabilis no 1, the introgression might be the result of a spontaneous translocation.

At which generation did the transfer occur? The observed segregation for resistance in $F_{2}$ of $\mathrm{BC}_{2}$ is 14 resistant: 6 susceptible. The probability that it fits with $3: 1$ ratio is higher than 0.6 (table I). An event of recombination or of translocation occurred in $F_{1}$ or $\mathrm{BC}_{1}$. It was probably in $\mathrm{BC}_{1}$ since only 1 plant out of 4 was found to be resistant in $\mathrm{BC}_{2}$. Moreover, the segregation in $\mathrm{F}_{2}$ of $\mathrm{BC}_{2}$ indicates that there is no distortion in the transmission of the gene(s) of resistance. In any case, further investigations will be made by analysing larger progenies of reciprocal crosses between Lutin and heterozygous plants.

The behaviour towards $M$ naasi of the selected lines is the same as in Ae variabilis no 1. It is likely that all the resistance was transferred. We are checking this assumption by analysis of the segregation for resistance in the $F_{2}$ generation of a cross between a susceptible line of Ae variabilis and line no 1 used as the resistant parent in the programme.

A disomic addition line originating from another $\mathrm{BC}_{1}$ plant has recently been obtained, the additional pair carrying the gene(s) of resistance (unpublished data). Biochemical marking will be performed initially to define its homeologous group and to characterize the alien information in the recombinant lines.

More backcrosses to Lutin are needed to produce a resistant isogenic line. This latter, and Lutin will be grown in a $M$ naasi infested field to assess tolerance to the nematode and to check that the introgression has no negative effects on agronomical traits before using it in wheat breeding. Thus, we will be able to measure the incidence on yield due to the root knot nematode since up to now no cultivar has shown to be resistant.

\section{ACKNOWLEDGMENTS}

Financial support for the investigation by the CARNO$A E D A$ is gratefully acknowledged.

\section{REFERENCES}

Caubel G, Ritter M, Rivoal R (1972) Observations relatives à des attaques du nématode Meloidogyne naasi, Franklin sur céréales et graminées fourragères, dans l'Ouest de la France en 1970. CR Acad Agric Fr 351-356

Cook R, York PA (1981) Genetics of resistance to Heterodera averiae and Meloidogyne naasi. Proc 4th Int Barley Genet Symp Edinburgh. Edinburgh University Press, 418-434

Driscoll CJ, Quinn CJ (1970) Genetic variation in Triticum affecting the level of chromosome pairing in intergeneric hybrids. Can J Genet Cytol 12, 278-282

Esmenjaud D, Marzin H, Rivoal R (1987) Fortes attaques du nématode Heterodera avenae sur blé dur dans le Lauragais. Phytoma Def Cult 390, 25-27

Gooris J, d'Herde CJ (1977) Study on the biology of Meloidogyne naasi Franklin 1965. State Nematol Entomol Res Stn Merelbecke-Belgique, $165 \mathrm{p}$

Kilpatrick RA, Gilchrist L, Golden AM (1976) Root knot on wheat in Chile. Plant Dis Rep 60-135

Meagher JW (1977) World dissemination of the cereal cyst nematode (Heterodera avenae) and its potential as a pathogen of wheat. $J$ Nematol $9,9-15$

Miller TE, Reader SM, Singh D (1988) Spontaneous non-Robertsonian translocations between wheat chromosomes and an alien chromosome. Proc 7 th Int Wheat Genet Symp Cambridge, 387-390

Person-Dedryver F (1984) Les céréales à paille hôtes de Meloidogyne naasi Franklin. I - Mise au point de méthodes et résultats préliminaires d'évaluation de la résistance ou du caractère multiplicateur. Agronomie 4, 977-985

Person-Dedryver F (1985) Les céréales à paille hôtes de Meloidogyne naasi Franklin. II - Variabilité du comportement multiplicateur ou résistant de variétés cultivées en France. Agronomie 5, 55-62

Person-Dedryver F (1986) Incidence du nématode à galle Meloidogyne naasi en cultures céréalières, méthodes de lutte. In: Les rotations céréalières intensives. Dix années d'études concertées INRA-ONIC-ITCF, 1973-1983. INRA, Paris 1986, 175-187

Person-Dedryver F, Jahier J (1985) Les céréales à paille, hôtes de Meloidogyne naasi Franklin. III. Recherches de sources de résistance parmi les espèces voisines du blé tendre. Agronomie 5, 573-578

Rivoal R, Sarr E (1987) Field experiments on Heterodera avenae in France and implications for winter wheat peformance. Nematologica 33, 460-479 